УДК: 37.091.2:378.6:355(477)

DOI: 10.26697/ijes.2019.4.1

\section{Соціокультурні \\ передумови \\ становлення системи військової освіти у \\ контексті забезпечення безпеки та оборони держави}

\section{Старший науковий співробітник Бабак С. А. ${ }^{1}$, доцент Круть П. П. ${ }^{1}$ \\ ${ }^{1}$ Харківський начіональний університет
внутрішніх справ, Украйна}

\section{Резюме.}

\section{Вступ:}

Необхідність корегування підходів, форм і способів здійснення сучасними державами власної політики безпеки та оборони, підготовки та ведення збройної боротьби потребує використання потужностей міждисциплінарного підходу для аналізу соціокультурних передумов становлення нової парадигми військової освіти як провідного чинника системи захисту життєвоважливих національних інтересів. Філософсько-освітня концептуалізація базових соціокультурних засад професійної підготовки та формування військового суб'єктапрофесіонала дозволяє постійно уточнювати соціальні та когнітивні виміри інституціоналізації інноваційної моделі системи військової освіти, які уможливлюють створення актуального та дієвого комплексу знань та компетентностей, вмінь та навичок для належної готовності надійно i гарантовано виконати завдання, що покладені на особовий склад силових компонентів сектору безпеки та оборони сучасної країни.

\section{Результати:}

Система військової освіти повинна забезпечити підготовку військових фахівців із належним рівнем професіоналізму, всебічної компетентності, інтелектуального і фізичного розвитку, загальної та військово-професійної культури, здатних ефективно виконувати поставленні завдання щодо оборони України. По суті ми стоїмо перед дилемою вирішення суперечливої задачі досягнення достатньої якості підготовки військових фахівців за наявності низки зазначених граничних умов i спроможностей, що загалом можна охарактеризувати як стан невизначеності 3 тенденцією до зниження навіть існуючого потенціалу військової освіти.

Сучасний аналіз освітніх проблем підготовки та застосування силових компонентів сектору безпеки та оборони України потребує використання складносистемного виміру дослідження процесу формування суб'єкта-професіонала, котрий безпосереднє здійснює реалізацію та захист життєво важливих інтересів громадянина, суспільства та держави. Актуальні зміни в системі військової освіті спричинені низкою соціокультурних обставин. Зокрема, вони викликані системною кризою сучасного суспільства, яка критично ускладнює належне функціонування базових соціальних інститутів, 3 причин зростання небезпек радикалізації та архаїзації соціокультурного буття людства.

Освіта як соціальний інститут відповідно реагує на зазначенні зрушення, що відбуваються в у звичних політико-економічних та культурних інструментах управління суспільством, які щойно втрачають належну дієвість у сфері подолання складного комплексу протиріч та загрозливих конфліктів. За рахунок поширення інформаційно-освітніх технологій змінюється характер усіх сфер соціального життя. Якщо об'єктом накопичення в індустріальному суспільстві були влада, фінанси, ресурси, то в інформаційному їм протистоять знання, професійна та “цифрова компетентність”. Відбулися зміни й в екзистенційній ситуації людства у контексті стрімкого зростання динамізму, непередбаченості, випадковості та нестійкості. У просторі існування людства створюються складні зони ризику й невизначеності. Для збереження соціального порядку та суспільної стійкості, потужними політичними центрами сили використовуються жорсткі форми силового (гібридно-військового) примусу, у контексті штучного створення криз, конфліктів та $30 \mathrm{H}$ небезпечного напруження в усіх регіонах світу.

\begin{abstract}
Висновки:
На сучасному етапі розвитку світової цивілізації освіта виступає інтелектуально-духовною, інвестиційною основою розвитку особистості, суспільства та держави, важливим чинником i стратегічним ресурсом забезпечення незалежності, національної безпеки i оборони, поліпшення добробуту людей. Аналіз соціокультурних передумов становлення нової парадигми військової освіти спирається на особливості репрезентації сучасної наукової картини світу, якій свідчить про системну кризу раціоналістичного світогляду. Наразі особливого значення набуває актуальний світоглядний підхід: військова освіта та опанування наукового знання набуває статусу екзистенційного пошуку, які мають завдання 3 частково вузькопрофесійної діяльності перетворитися на смисложиттєву орієнтацію.
\end{abstract}

Інформація про авторів:
Бабак Сергій Анатолійович - кандидат військових наук, старший науковий співробітник, завідувач кафедри військової підготовки, Харківський національний університет внутрішніх справ, Харків, Україна.

Наукові інтереси: педагогіка, військова освіта; https://orcid.org/0000-0002-2248-454X.

Круть Петро Павлович - кандидат філософських наук, доцент, доцент кафедри військової підготовки, Харківський національний університет внутрішніх справ, Харків, Україна.

Наукові інтереси: психологія, філософія, педагогіка; https://orcid.org/0000-0003-4554-7870.

Автор-Кореспондент:

Круть Петро Павлович

Email Автора-Кореспондента:

pkrut63@yahoo.com 